\title{
Analysis of Adapted Sewage Sludge Treatment and Disposal Routes in Bujumbura, Burundi
}

\author{
Aaron Bizimana, Bing Wu*, Aicha Abdallah Idriss \\ UNEP-Tongji Institute of Environment for Sustainable Development (IESD), College of Environmental Science and Engineering, \\ State Key Laboratory of Pollution Control and Resource Reuse Study, Tongji University, Shanghai, China \\ Email: ^bingwu@tongji.edu.cn
}

How to cite this paper: Bizimana, A., $\mathrm{Wu}$, B. and Idriss, A.A. (2021) Analysis of Adapted Sewage Sludge Treatment and Disposal Routes in Bujumbura, Burundi. Open Access Library Journal, 8: e7319. https://doi.org/10.4236/oalib.1107319

Received: January 4, 2021

Accepted: April 26, 2021

Published: April 29, 2021

Copyright ( $\odot 2021$ by author(s) and Open Access Library Inc.

This work is licensed under the Creative Commons Attribution International License (CC BY 4.0).

http://creativecommons.org/licenses/by/4.0/

(c) (i) Open Access

\begin{abstract}
The disparities found in studies on sewage sludge management, aggravated by the high financial investment required, may lead to decision-making uncertainty and hesitancy. This research, basing on seven different sludge treatment and disposal routes that are widely used in China (thickening-anaerobic digestion-dewatering-land application, thickening-conditioning-dewatering-sanitary landfill; thickening-conditioning-dewateringanaerobic digestion-land application, thickening-conditioning-dewateringdrying-incineration; thickening-conditioning-dewatering-drying-land application; thickening-conditioning-dewatering-incineration-sanitary landfill and thickening-conditioning-dewatering-drying-sintering-building materials), and a contextual assessment of major influencing indicators in Bujumbura through a review of priorities defined in the country National Development Plan 2018-2027 and other relevant reports from the government and different local and international organizations, selected five key factors such as energy recovery, local policies and priorities, weather conditions, environmental impact rate, and capital investment, and analyzed which routes are more adapted for this city. Thus, an assessment matrix for suitability of each of the seven routes to each factor was developed to summarize the advantages and disadvantages for each scenario. The analysis results demonstrated that the financial capacity excludes incineration process. Energy recovery-oriented routes are likely to be particularly attractive due to their potential of producing electricity which is scarce in this city. The treatment should apply drying before disposal, a cost-free process using natural drying to reduce the cost and eventual environmental impact during sludge transportation to the disposal site. Landfilling is preferable over land application, to prevent the potential risk posed by the geographic position and topographic condition of the city. The study concluded that a route using anaerobic digestion, drying and landfilling would be a good choice for the
\end{abstract}


area studied.

\section{Subject Areas}

Environmental Sciences

\section{Keywords}

Sludge Management, Environmental Impact, Policy, Energy Recovery, Sustainability

\section{Introduction}

Sludge is the substance that is removed from the sewage treatment process by settling, flotation, or filtration at different levels. The waste dumped into the sewerage system, the method of sewage treatment, the operation of the facility, and the procedure to which the sludge has been subjected all influence its chemical, biological, and physical characteristics. Pathogens, heavy metals, organic materials, and unfavorable chemical elements may all be present. The characteristics of sludge differ greatly from one place to the next and over time within the same facility. The presence of hazardous elements in sewage sludge has led to a considerable number of researches to assess the health risks associated with the land applications of sludge, and unanimously recommend that before land application, regular monitoring and stabilization of sewage sludge are required to ensure the protection of public health [1]. FAO (Food and Agriculture Organization of the United Nations) provides key guidelines for "Agricultural use of sewage sludge" (available at http://www.fao.org/), to be respected where land application is used. Firstly, category of materials which are excluded such as plastics, secondly the odor control during the transportation, must use an appropriate vehicle type to avoid eventual inconvenience on the way, and lastly, must prevent leaking from land to surrounding infrastructures.

The negative impacts of sludge are not only environmental but also enormously economic, given that the treatment and disposal of sludge generated in the process may account for up to $60 \%$ of the total operating expenses in a wastewater treatment plant [2] [3]. The economy being at the center of each nation's priorities in the modern world, the involvement of huge capital expenditure exacerbates the reluctance in decision making. All these above-mentioned factors drive into such a dilemma when considering what advanced treatment method to adopt, due to the large number of methods existing and the discrepancies observed.

However, the sludge treatment technologies comprise several methods from which a better choice can be made, and the present studies propose an approach of linking advantages and disadvantages of each method to the key factors such as local policies, geographic location, weather condition (temperature, solar rad- 
iation), etc., which affect positively or negatively, directly or indirectly the sludge treatment process and then confuse decision making.

Despite environmental and economic restrictions, sludge is still regarded as a resource instead of waste, due to its various applications with potential to offset at short or long-run the treatment and disposal cost, which corresponds to the circular economy concept [4]. Many countries have already recognized that sewage sludge components can be recycled in a new strategy which is aimed at making products from sludge which are in-tended for sale in the market place, while other sludge based products can be used for energy and also reused with matter recovery for land application [5]. Moreover, the reuse of sludge and/or ash sludge in production of construction material also corresponds to the circular economy concept and can solve the massive sludge disposal problems, remaining a "safe" prerequisite [6].

Thus, this study aims to propose an economically and environmentally friendly sewage sludge treatment and disposal route adapted to the context of Bujumbura, in Burundi.

\section{Methodology}

This study is on one hand based on a general literature review related to sewage sludge treatment and disposal methods, and on the other hand an assessment of the key local indicators and conditions. Therefore, we searched in bibliometric databases such as Google Scholar, Research gate, Web of Science, ScienceDirect, with various keywords in different combinations: sludge management, environmental impact, policy, energy recovery, sustainability, etc. Also, we reviewed reports published by the government and non-governmental organizations operating in the area concerned, especially the "Plan National de Développement 2018-2027" [7] or the National Development Plan 2018-2027 of Burundi, the document containing the investment priorities and which is guiding all the sectors of life to attain the committed goals. Relevant sustainable development goals (SDGs) were also reviewed to have a clear understanding of the government's stance about combating climate change, which allows or limits the scenarios of this research.

\section{Description of the Study Area}

\subsection{Geographical Location}

Bujumbura is the largest and economic capital city of Burundi, a country located in the heart of Africa with a population of 11.89 million (2020), surrounded by Rwanda to the north, Tanzania to the east, the Democratic Republic of Congo to the west, and bordered by Lake Tanganyika to the southwest (Figure 1). Bujumbura is located in the western part of the country, on the shores of Lake Tanganyika. The city of Bujumbura is stuck between the lake to the west and the Mumirwa hills to the east. Its altitude is between 800 and 100 meters, well below the rest of the country, whose average altitude is 1500 meters. Its topography is 

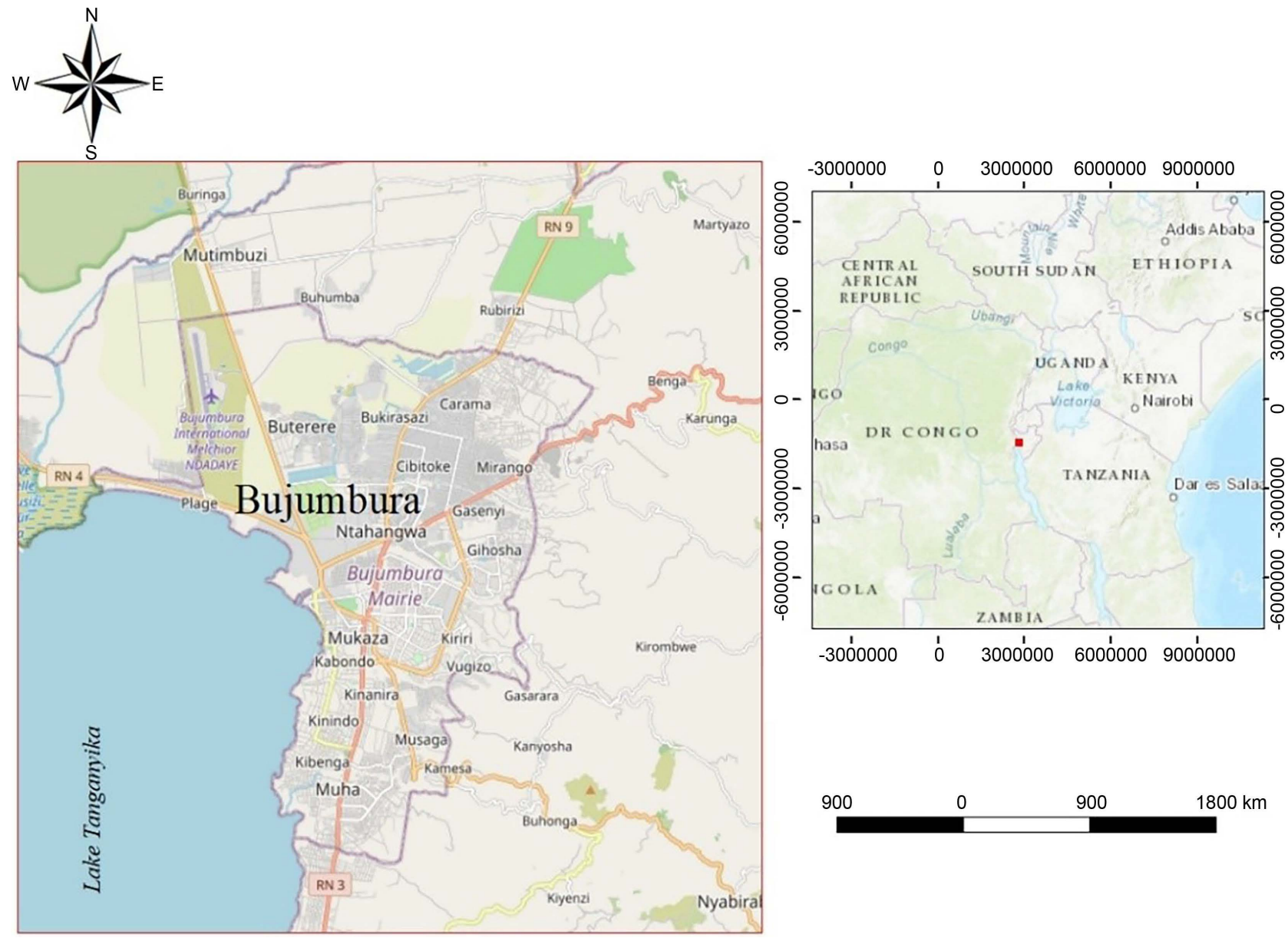

Figure 1. Location map of Bujumbura.

relatively complex, as it is traversed by a series of several parallels, relatively and regularly spaced rivers flowing from east to west (in the lake). With an area of $86.52 \mathrm{~km}^{2}$, Bujumbura is the biggest city of Burundi with a population estimated at $1,012,996$ inhabitants and $6.17 \%$ of growth rate (World Population Data 2020). It is the administrative and economic capital city of Burundi, and it is there that the majority of the country's industrial activities are concentrated.

\subsection{Sanitation and Pollution Level}

Health coverage at the level of the town hall represents only 5.9\% of households. Regarding wastewater management, it is estimated that the city has more than 60,000 septic tanks and latrines to be emptied and more than $420 \mathrm{~km}$ of sewage network. Insufficient treatment facility is also an evidence, as the city has only one wastewater treatment plant while experts estimate a need of at least three plants [8].

The sanitation rate in Bujumbura and Burundi in general is still critically low. According to the statistics of 2018, only $27 \%$ and $15 \%$ respectively of the urban and rural population had access to adequate sanitation facilities and $16 \%$ at the national level [7] (Figure 2). 


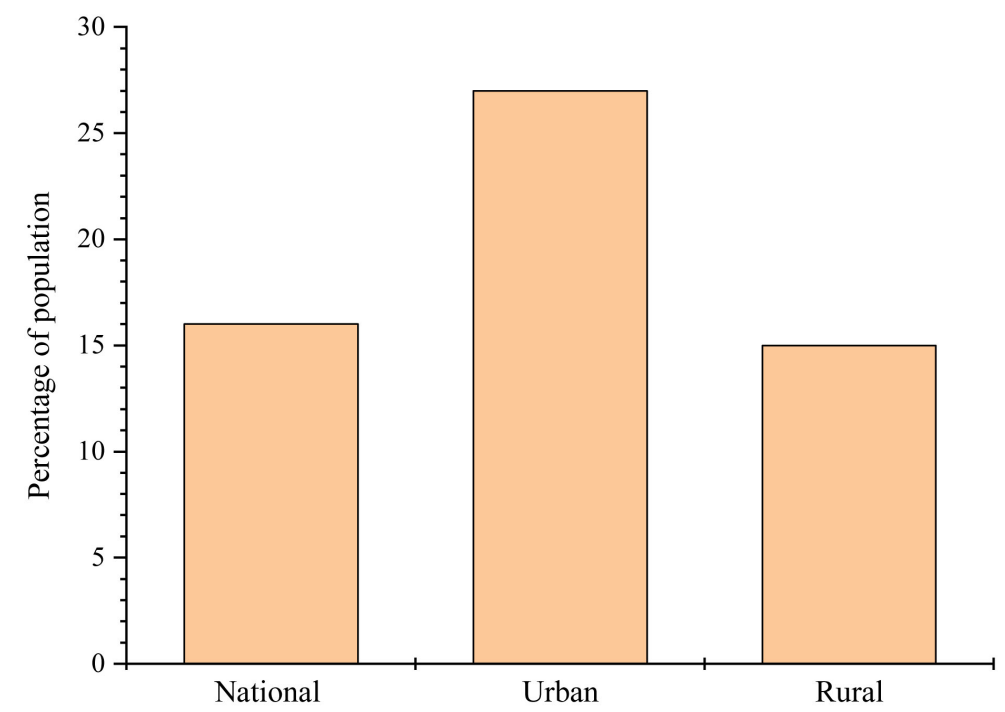

Figure 2. Percentage of population using basic sanitation services (2015).

The improper sanitation in Bujumbura constitutes a potential risk to Lake Tanganyika, the precious water reservoir for cities around it in the four riparian countries (Burundi, Democratic Republic of Congo, Tanzania and Zambia), and consequences are heavy to the life of the residents of these cities. Bujumbura is the largest city of the group, should be an example for the rest and lead anti-pollution actions. In addition to blackwaters and industrial wastewaters management, this study also investigated the current practices in greywater discharge, and presents an insight of 4 districts over the eight in total, in the former city structure (Table 1). With a gutter discharge rate averaging 67 percent for shower greywater and 84.5 percent for kitchen greywater, the improper discharge rate is considerably higher.

Lake Tanganyika is one of the earth's major ecosystems and one of the seven African Great Lakes namely Albert, Edward, Kivu, Malawi/Nyasa/Niassa, Turkana, and Victoria. Three of these lakes (Victoria, Tanganyika, and Malawi) hold one-quarter of the earth's total surface water supply. Their fisheries are abundant and sustain more than 50 million people. They are home to the world's richest lacustrine fish fauna, but they are currently facing serious challenges in their respective catchment basins, including water contamination, overfishing, increased deforestation, land loss, and overgrazing [10]. The pollution caused by such practices is an evidence in Lake Tanganyika (Figure 3), a lake which is important not only for its endangered species, but also as a microcosm in which to research evolutionary processes. The lake's significance to global biodiversity is immeasurable.

\subsection{Health Impact}

Water pollution is the leading worldwide cause of death and disease, e.g. due to water-borne diseases. Therefore, a synergy for safe sanitation systems is essential to protect public health. In this perspective, World Health Organization (WHO) 
Table 1. Improper discharge of grey waters in Bujumbura (Unit: \%).

\begin{tabular}{ccccc}
\hline Greywater category & Musaga & Kinindo & Cibitoke & Kinama \\
\hline Shower & $59^{\mathrm{a}} ; 37^{\mathrm{c}}$ & $85^{\mathrm{b}}$ & $83.45^{\mathrm{c}}$ & $80.71^{\mathrm{c}}$ \\
Kitchen & $97^{\mathrm{c}}$ & $52^{\mathrm{b}} ; 46^{\mathrm{c}}$ & $98.64^{\mathrm{c}}$ & $96.5^{\mathrm{c}}$ \\
\hline
\end{tabular}

Legend: a: In septic tank, b: Lost well, c: Gutters (Adapted from [9]).

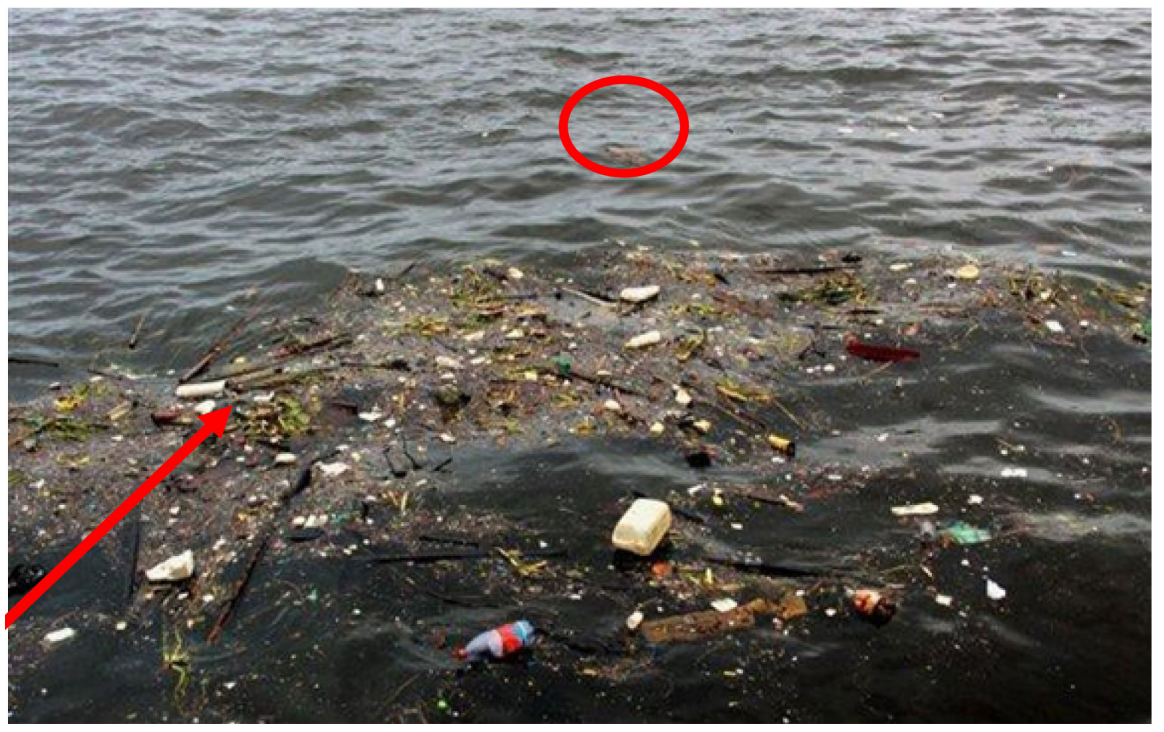

Figure 3. The pollution of Lake Tanganyika.

is leading efforts to monitor the global burden of sanitation-related disease, access to safe sanitation and wastewater treatment, as well as factors that help or impede progress toward the Sustainable Development Goals. The helminthiasis prevalence was found higher in different Communes of Bujumbura, in a study conducted in 2012 based on laboratory results of stool examinations (number of pathological cases per Commune, per year, and age group) [9]. Apart from the hookworm where contamination is transcutaneous, mainly due to walking barefoot on soil polluted by human excreta, other helminthiases are fecal-oral diseases (diseases due to water contamination or food through excreta) [9]. Their prevalence in the Communes surveyed is potentially linked with the poor sanitation systems in households as well as the sources of water supplied.

\subsection{Economic Impact}

Heavy financial cost of water pollution is a global challenge which does not spare Bujumbura or Burundi in general. Based on the individual cost estimates for 4 major categories such as deforestation and land degradation, air pollution, water pollution and natural disasters, the total cost of environmental degradation (COED) in Burundi was estimated at US\$376 million or 12.1 percent of the country's GDP in 2014 [11]. The cost related to water pollution occupied the second place with $31 \%$ of the total environmental expenses, after deforestation and land degradation which accounted for $33 \%$ (Figure 4 ). 


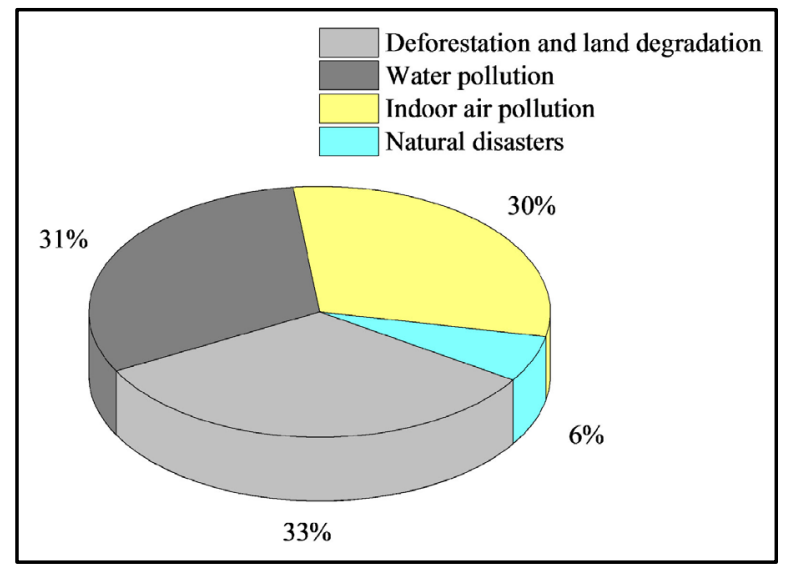

Figure 4. Proportion of environmental consumption by sector in Burundi.

\section{Sewage Sludge Production and Management in Bujumbura}

In this section, we first surveyed the major sources of sewage, collection modes used, and treatment methods. Then, we gathered the quantity of sludge produced, the treatment mode, disposal method, as well as existing utilizations.

\subsection{Sewage Production in Bujumbura}

Sewage in Bujumbura is produced by its population currently estimated at $1,012,996$ inhabitants with a growth rate reaching $6.17 \%$, and by the major companies and factories of the countries such as the Brasserie du Burundi (BRARUDI), the Bujumbura slaughterhouse (SOGEAB), the tannery (AFRITAN), and the textile factory (AFRITEXTILE) [12].

A report of 2012 estimated that $75,000,000 \mathrm{~m}^{3}$ of sewage was produced throughout Bujumbura city each year, but the collection capacity from the sewer grid was only $11,000,000 \mathrm{~m}^{3}$ per year. Of this quantity of sewage collected, only $1,020,000 \mathrm{~m}^{3}$ was treated per year by the wastewater treatment plant due to the non-connection of some neighborhoods to the sewer grid [8].

\subsection{Sewage Collection Modes}

There are currently three modes of sewage collection which are pit-latrine, septage (autonomous mode), and sewer grid system (collective mode). In 2018, the collective mode represented 30\% while the autonomous mode represented $70 \%$ using pit-latrines (Figure $5(\mathrm{c})$ ). Greywater is conveyed by the collective mode but the black-water is transported by collective according to its availability and accessibility. The Communes producing higher amounts of sludge are not the ones having denser collective grid, or do not even have access to it (Figure 5(a)) and Figure 5(b)). For instance, Ngagara does not produce higher amount of sewage (Figure 5(a)) but has more wastewater transported by collective mode, which might be due to the relatively higher availability of collective network [12]. 


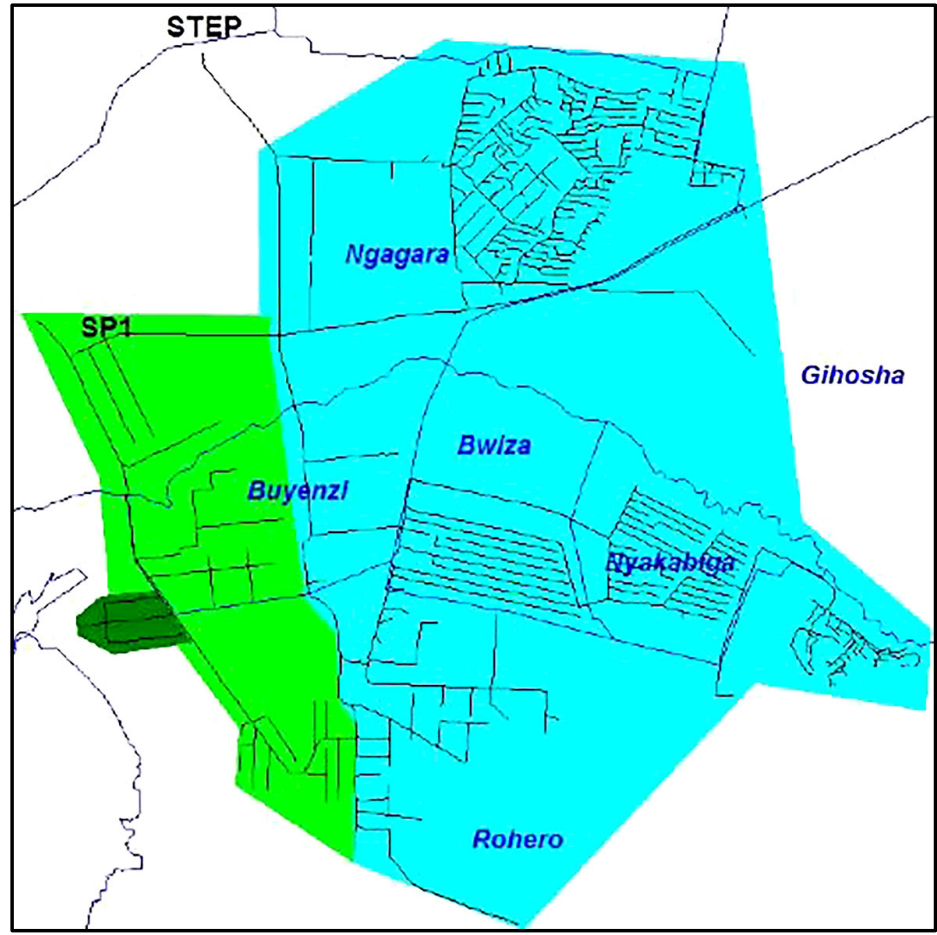

(a)

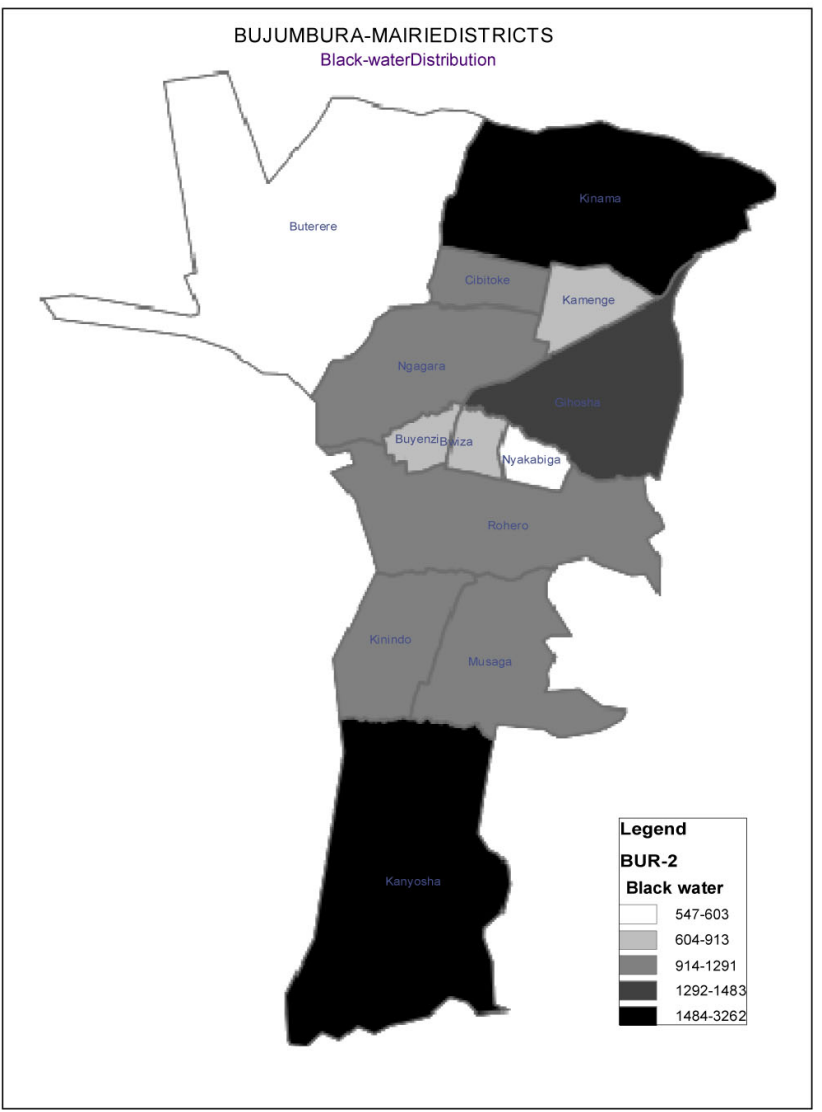

(b)

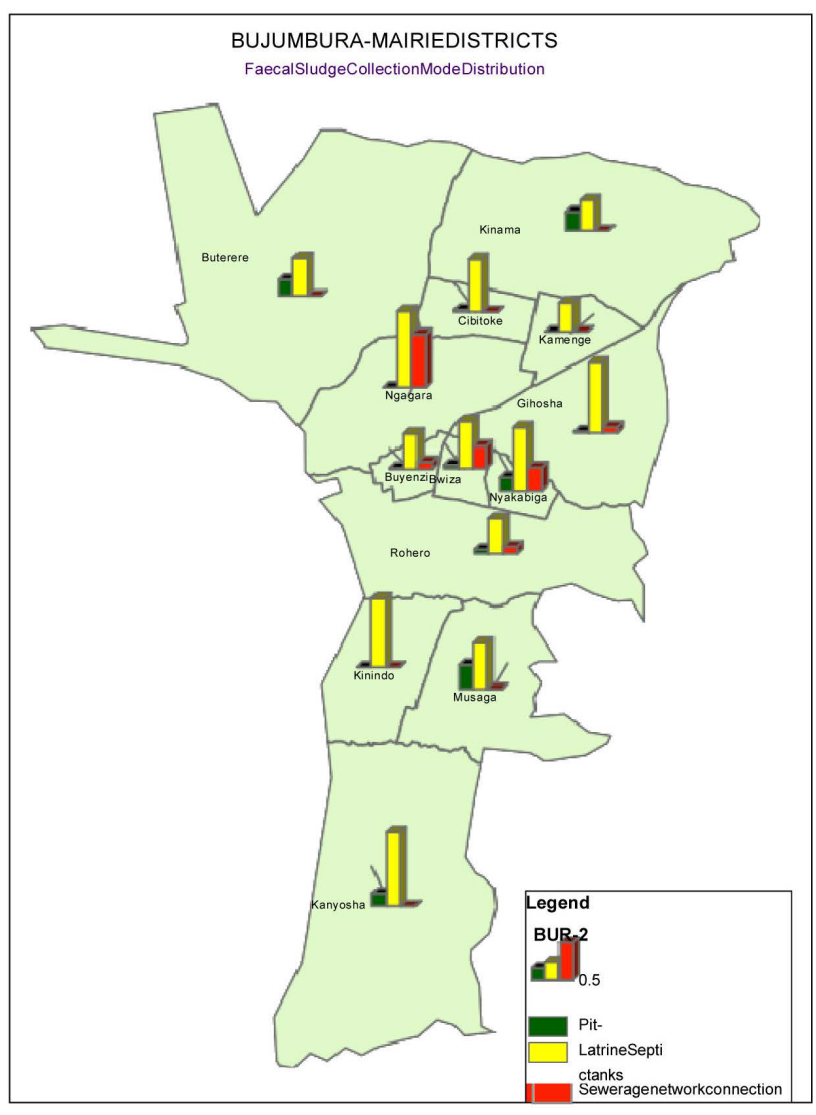

(c)

Figure 5. Maps of sewer grid availability, black water production and fecal sludge collection mode in the Communes of Bujumbura. (a) Centralized grid availability. (b) Black water distribution (c) Sludge collection mode. 
The configuration of the autonomous systems used by households in the city of Bujumbura and the results show that the households that use the septic tank own the water from the Regideso (the national company for water and electricity supply) to the house, the habitat is mainly of high standing or medium standing and the sludge emptying is done by specialized truck with unloading in the WWTP. On the other side, those who use the pit-latrine get their water supply by a public faucet in general, the habitat is mainly low standing and when the latrine is full, they make another pit or empty the sludge manually with illegal dumping [9]. The domestic gray waters indistinctly consist of a discharge into the gutters without any treatment.

Regarding sewage pumping stations (PS), the city has altogether 4 PS that work in series (PS2 and PS3 to PS1 to PS4). Pumping station $\mathrm{N}^{\circ} 4$ is located at the Buterere wastewater treatment plant (WWTP). Due to the incomplete connection to sewage sources, the station is underused, the volume of treated water remains less than its capacity and as a result, issues related to sanitation and climate change remain [12].

Besides the amounts received through the collective network, there are seven private emptying companies (BGC, SEE, Marcus, Andrew cat, Mbasha, RUKARA, BUNIB) that discharge $2000 \mathrm{~m}^{3}$ per month, in the lagoons of the Buterere wastewater treatment plant.

\subsection{Treatment and Disposal Methods}

The sewage treatment plant of Bujumbura (known as Buterere WWTP) is for the time being the unique existing plant in Bujumbura, and in Burundi as a whole. This plant is using a technique of biological lagooning, and the system consists of six anaerobic lagoons, arranged in parallel 3 to 3 , receiving raw sewage. Sludge deposits are constantly formed, that need to be removed regularly. Technical problems were affecting the plant's efficiency at the time of this study, but maintenance and rehabilitation projects were about to begin. When a functioning failure occurs in such system, as the amount of sludge increases, the retention time in the lagoon decreases, impacting the sewage treatment process. Moreover, when there is decrease of retention time in the lagoons, the bacteria do not have the time necessary to transform the organic matter, and consequently, at some point sludge has to be evacuated from the lagoons before being taken to the drying beds, where it is treated to reduce its volume.

Despite the rapid city expansion and population increase in Bujumbura, the development of sanitation facilities does not seem to be following the pace. Data of a six-year period between 2011 to 2016 indicate that among the facilities, only the sewer grid increased in length from $145 \mathrm{~km}$ to $200 \mathrm{~km}$, the number of lagoons, drying beds and pumping station remaining constant (Table 2). Over the same period, the quantity of sewage emptied by autonomous systems increased sharply, whereas the quantity of sewage treated at Buterere WWTP showed opposite trend from 2014 to 2016 (Figure 6 and Figure 7). 
Table 2. Sewage collection and treatment facilities and their evolution.

\begin{tabular}{ccccccc}
\hline & 2011 & 2012 & 2013 & 2014 & 2015 & 2016 \\
\hline Length of the Network (km) & 145 & 145 & 145 & 200 & 200 & 200 \\
Lagunas (number) & 6 & 6 & 6 & 6 & 6 & 6 \\
Drying beds (number) & 18 & 18 & 18 & 18 & 18 & 18 \\
Pumping station (number) & 4 & 4 & 4 & 4 & 4 & 4 \\
\hline
\end{tabular}

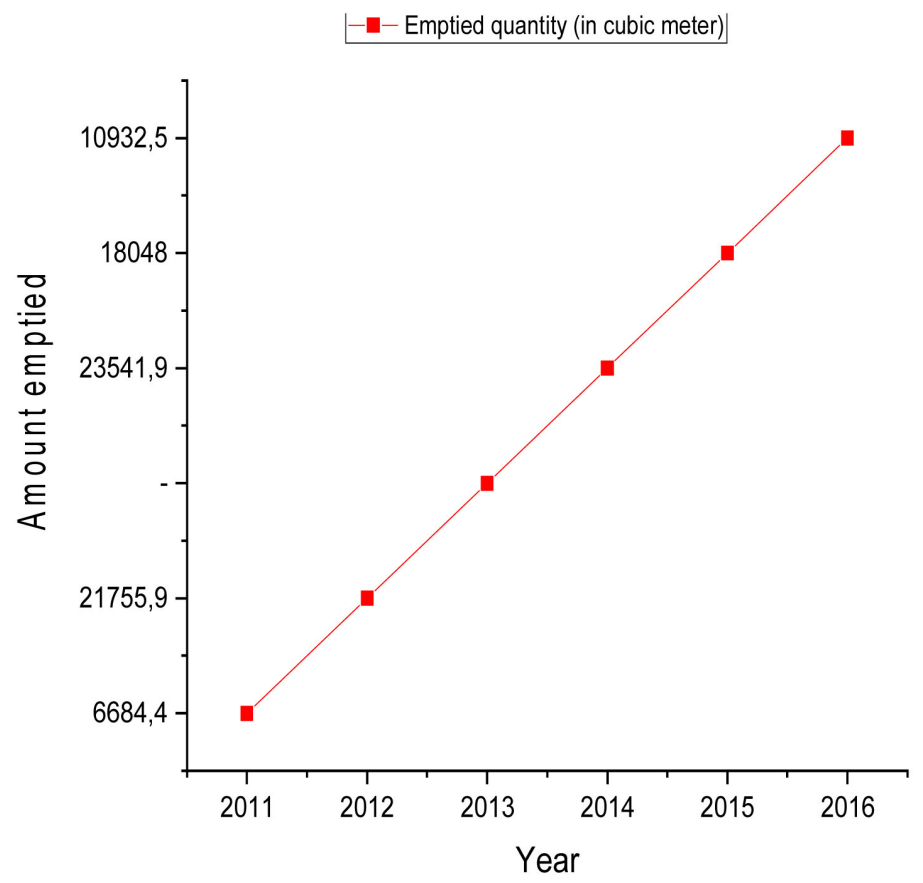

Figure 6. Sewage emptied by autonomous systems.

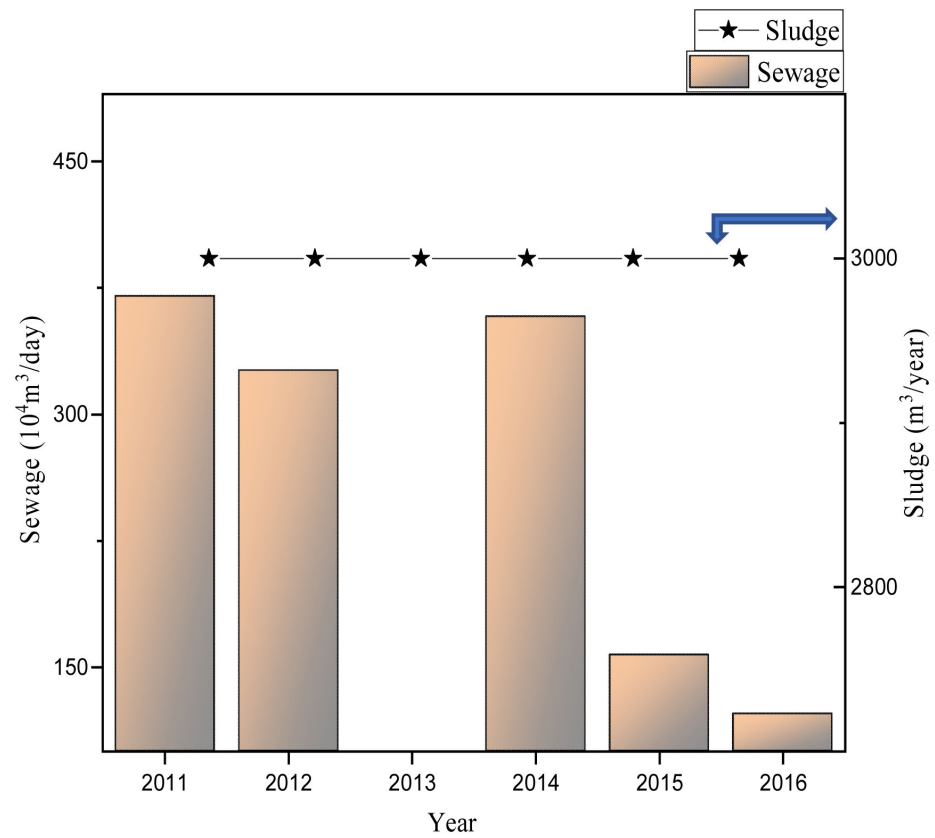

Figure 7. Quantity of sewage treated at Buterere WWTP. 


\subsection{Conventional Treatment}

The sludge released by WWTPs still has a high moisture content, typically of $80 \%$ after process in thickening and dewatering units, which allow the production of dewatered sludge with an approximate solid's concentration of $20 \%$ $30 \%$ [13] [14]. To reduce this moisture content, generally the drying process is applied before disposal. Drying constitutes an important process for wastewater sludge management, as it can reduce significantly the mass and the volume of the product, and consequently the cost of storage, handling, and transport [14] [15]. The different techniques of drying are natural drying (also known as solar drying), mechanical drying, thermal drying [16] [17] [18]. In other cases, only storage is used in many options such as a silo, bag, storage area, tank, tarp, shed, bucket, geotube, laguna, or decanter [18]. Options for the sludge treatment process are plenty and the final choices are mainly guided by the ultimate disposal goals [19]. For instance, the processes of dewatering, composting, and drying will be important for agricultural use, whereas dewatering and drying will be important for incineration options (mono- and co-incineration) [19] [20].

The selection of appropriate technology for sludge management depends on the minimization of total capital cost but other important factors such as local geography, climate, land use, regulatory constraints as well as public acceptance of various practices, frequently play an equally significant role [21]. In countries that are technologically less developed, direct agricultural application or landfilling are still the typical pathways to safely dispose of stabilized sludge from wastewater treatment [22]. However, studies suggest that sludge should not be sent to the agricultural sites given the number of micronutrients contained such as iron, zinc, copper, and manganese and macronutrients such as carbon, nitrogen, and phosphorus [16] [23] [24]. Therefore, in countries where policymakers had practically forbidden such solutions (e.g., the European Union), only thermal disposal methods are available [22]. The thermochemical conversion of sewage sludge consists of four main processes: combustion, co-combustion, pyrolysis, and gasification [22].

Incineration of sewage sludge (70\%) and landfill application is the main disposal route in Japan, while in South Korea sewage sludge was dumped into the sea until 2012, but since past few years there was a shift towards landfill application [25]. Whichever process chosen should be friendly to the environment. For instance, if the landfill is selected, it should be sanitary with a leachate treatment system consisting of processes that generate a sludge which must be disposed of in a way that minimizes its environmental impacts [26] [27].

\section{Assessment, Basis, and Scope}

\subsection{Scope Definition}

This section presents the potential indicators assessed in Bujumbura, and the systematic approach used to reach the objectives of the study. First, our references are official reports and relevant papers reviewed. One of the major chal- 
lenges was the discrepancies observed in reviewed scientific studies which sometimes leads to confusion. Therefore, among the tones of studies published on sewage treatment and disposal methods, we selected one, a comprehensive study conducted in China, in 2015 [27]. The treatment and disposal routes used in China were then used as the basis of our study (Figure 8).

The results showed that in the context of China, Technical Route 1 (TR1) demonstrated great potentials to be the main technical route of sludge treatment and disposal, because if it was adopted in the whole China, more than 2.5 billion $\mathrm{m}^{3}$ of biogas would be produced within one year, which can generate more than 4 billion kWh electricity [28]. The same seven routes were adopted to serve as references to this study, in the analysis of the suitable route for our study area, Bujumbura city. Thus, the study proceeded with an assessment of advantages and disadvantages of each of these routes to the key relevant characteristics including weather conditions, local policies and priorities, investment cost versus local financial situation, their environmental impact rate, etc. Thus, we needed to define the key factors to consider when selecting a route for a specific city or region.

\subsection{Key Factors Selected}

To assess the above-presented routes, key indicators (hereinafter referred to as factors) were selected and analyzed. We reviewed the current local and international policies and priority sectors applicable in Bujumbura, especially those listed in the National Development Plan 2018-2027 [7].

\subsubsection{Factor 1: Energy}

Currently, the energy sector in Burundi is mainly dominated by traditional energies (wood, charcoal, biomass, etc.) and modern energy (electricity and petroleum products). About $98 \%$ of the population, both urban and rural, use wood and charcoal as a source of energy especially for heating and cooking food; which accentuates the deforestation estimated at 2\% per year in 2013-2014. Of a hydroelectric potential estimated at $1700 \mathrm{MW}$, only $300 \mathrm{MW}$ are technically and

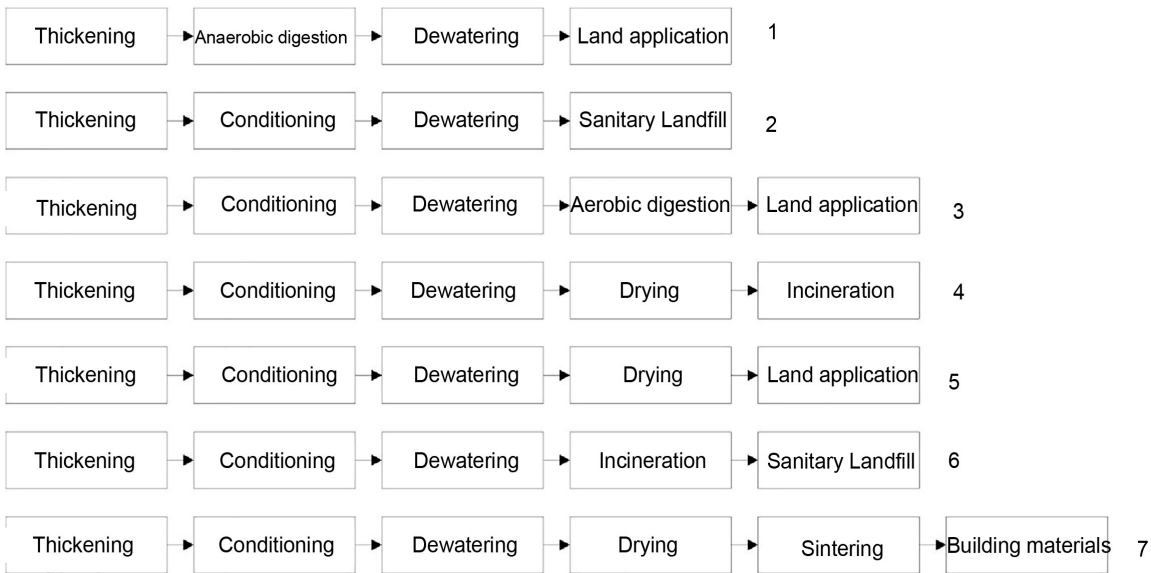

Figure 8. Main technical routes of sludge treatment and disposal in China [28]. 
economically exploitable. The installed electrical power is currently close to 50 MW, including 32.9 MW of national production of hydraulic origin. Electricity consumption is very low and is less than $30 \mathrm{kWh}$ per capita per year, which is by far below the African average estimated at $150 \mathrm{kWh}$ per capita per year. The electricity access rate is less than $5 \%$ of the population and the number of households with access to electricity is estimated at 7\% corresponding to $52.1 \%$ of urban households and $2 \%$ of rural households [7].

Various energy development initiatives were introduced in the country since several decades ago, but the goals are not yet attained due to different crises that had been destabilizing the country. For instance, biogas technology was introduced in Burundi in the 1980s through a biogas project. From 1983 to 1995, more than 300 digesters were already installed across the country. The project aimed to contribute in solving the problem of energy supply and sanitation in rural areas. The raw material for the functioning of the first biogas plants consisted of animal waste. The biogas produced was mainly used for cooking and lighting. But, the socio-political crisis of 1993 did not allow the further development of this technology.

The development of the sector has great potential but faces several challenges: 1) increasing the energy supply; 2) demographic pressure; 3) rehabilitation and construction of infrastructure; 4) control of energy losses and production costs; 5) control of the petroleum products costs; 6) capacity building of personnel in the energy sector; 7) diversification of energy sources; 8) upkeep and maintenance of energy equipment; 9) the rational use of traditional energy sources (wood, charcoal,) and 10) the mitigation of climatic disturbances [7].

The historical data from 1996 to 2020 give an insight on how the energy sector evolution has always been characterized by a lack of a steadily progressive trend (Figure 9). Being dominated by hydropower, apparent reduction in energy availability is observed between July (mid-long dry season) and January (short dry season). This gap can be balanced by the development of solar energy and other forms of energy from the local resources. The imported energy from the hydropower dams shared with neighboring countries is the back born of the sector, by continuously contributing more than $50 \%$ of the total national production (Figure 10).

Electricity is still a bar of gold in Burundi, which brought different actors to search the resources available. Thus, the following biomass activities, including our case, were pointed out in a UNDP's energy development report, to be interesting: electricity production based on waste by direct burning or by methanation, peat-based electricity production, the use of sugar cane residues (bagasse) to produce electricity.

In conclusion to this fact, it is obvious that any technology contributing to the energy sector in Bujumbura would be supported. Thus, here the special consideration would be given to the routes involving anaerobic digestion, incineration, pyrolysis or gasification, the four major technologies focusing on energy recovery. 


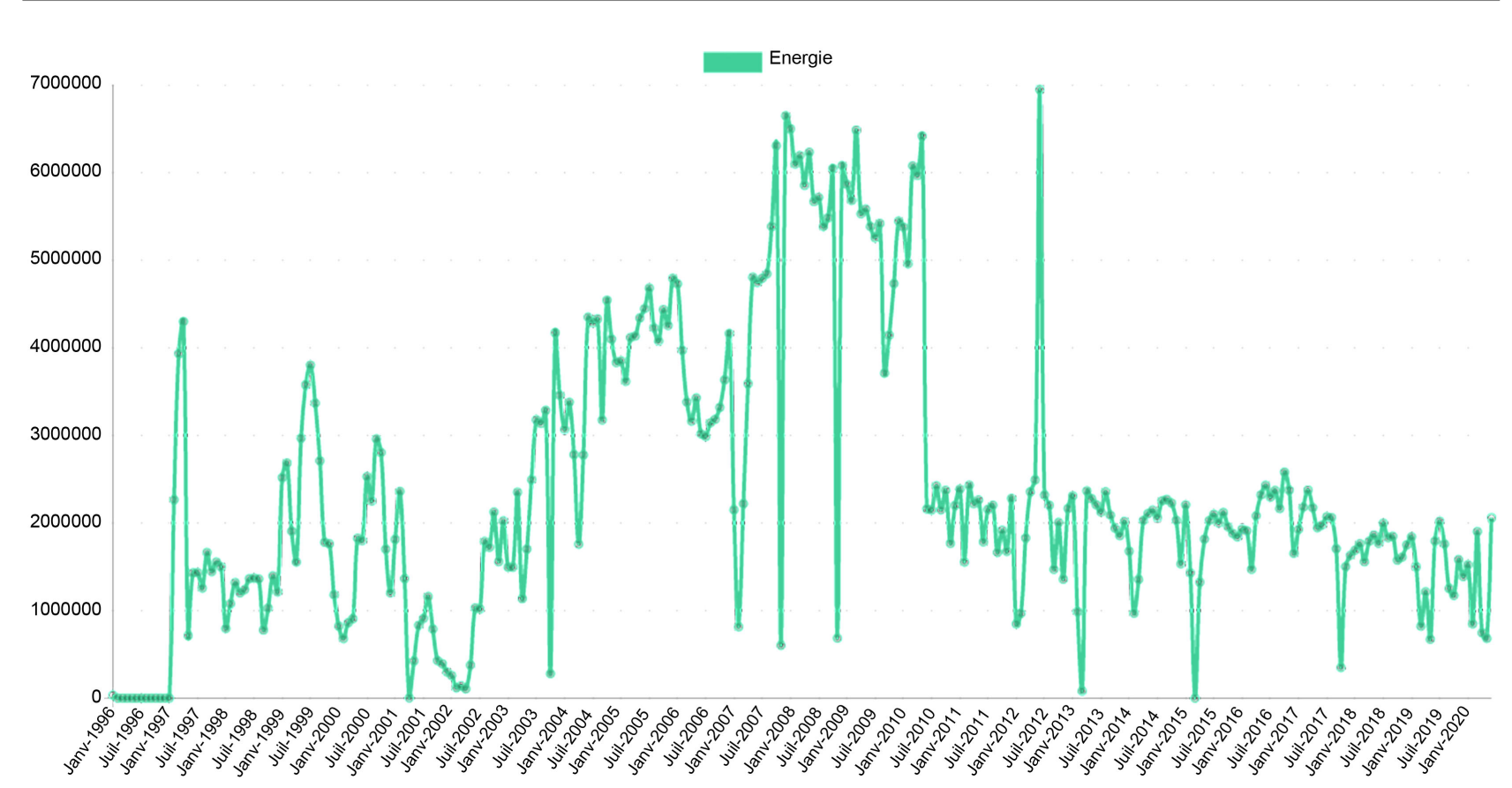

Figure 9. Evolution of electricity availability in Burundi in Mega Watts (Source: ISTEEBU, the Institute of Statistics and Economic Studies of Burundi).

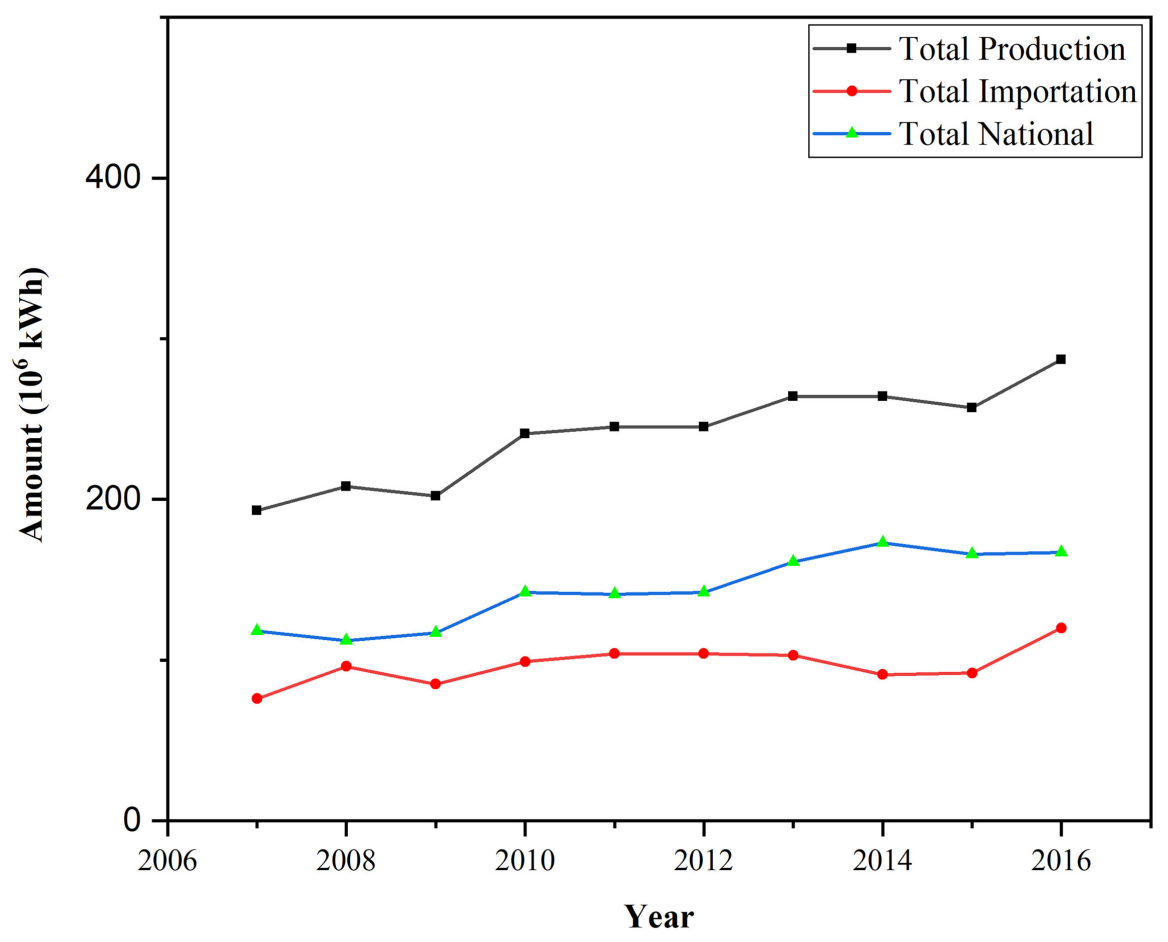

Figure 10. Electricity production inside and from outside of Burundi.

\subsubsection{Factor 2: Local Relevant Priorities}

We reviewed the top priorities of the moment which are in relationship with sewage sludge utilizations and the processes involved by different treatment and disposal routes defined in this study. There were no restrictions found in regard to technologies used by conventional methods. On the contrary, the NDP men- 
tioned two ultimate points:

- Biomass is one of the identified sources of energies to be developed, along with solar energy.

- Measures related to combatting climate change (SDG 13) are one of the priority targets at the national level for SDGs considered.

\subsubsection{Factor Three: Local Weather Conditions}

Weather conditions are one of the influencing factors when selecting a sludge treatment and disposal process. Burundi has been endowed with a tropical climate, which is a huge asset for sludge drying, given that using free solar energy for wastewater sludge drying can be a benefit in point of view of energy consumption and consequence on the cost of the drying system [15]. Therefore, the main indicators of weather conditions were surveyed: temperature, climate/ETo (evapotranspiration rate), humidity, sunshine, and radiation (Figure 11). The minimal and maximal temperatures remain respectively about $17^{\circ} \mathrm{C}$ and $29^{\circ} \mathrm{C}$, whereas solar radiation oscillates between 15 and $20 \mathrm{MJ} / \mathrm{m}^{3} /$ day. Statistics of annual temperature variation in Bujumbura obtained in the ISTEEBU database confirmed the software results viability, by even showing times where maximal temperatures reached $35^{\circ} \mathrm{C}$ in 2007, 2008, 2010 and 2013 (Figure 12). These conditions are very favorable for sludge drying with natural method.

\subsubsection{Factor Four: Financial Context}

This section is the most critical one and is a common challenge for most developing countries. Burundi's GDP (gross domestic product) was estimated at 3.012 billion USD, and the GDP per capita at 261.247 USD in 2019 (World Bank Data). To better understand this economic constraint, one can look at the budget required to build an incineration plant, one of the top-rated methods presently.

Waste-to-Energy International, basing on their construction experience and contacts with world top producers, provides an empirical formula to estimate the cost of incineration plant [29].

$$
I=2.3507 \times C^{0.7753}
$$

where: $I$ is the investment cost in million dollars and $C$ is the plant capacity (1000 metric tons of waste/year).

For instance, if we want to calculate the cost of a 100,000 tpa (tons per annum) plant, then $C=100$ (capacity in 1000 metric tons of waste/year). By a direct application, $I=83.5$ million USD.

So, CAPEX (capital expenditure) of a typical 100,000 tpa MSW incineration plant is 83.5 million USD.

The final total cost of the plant would be even higher since it depends multiple factors including location, country, type of incineration technology selected, usage of generators, boilers, and other peripheral equipment by local suppliers, architectural solutions, waste composition, and moisture, etc.

The data below show clearly how the construction of one incineration plant can be estimated at almost 6 times the annual budget of the then supervising 
(1) CLIMWAT 2.0 - Local Station Distribution

Exit Export New Location Stations Display Zoom In Zoom Out Export Selected Stations Colors Disclaimer About ?

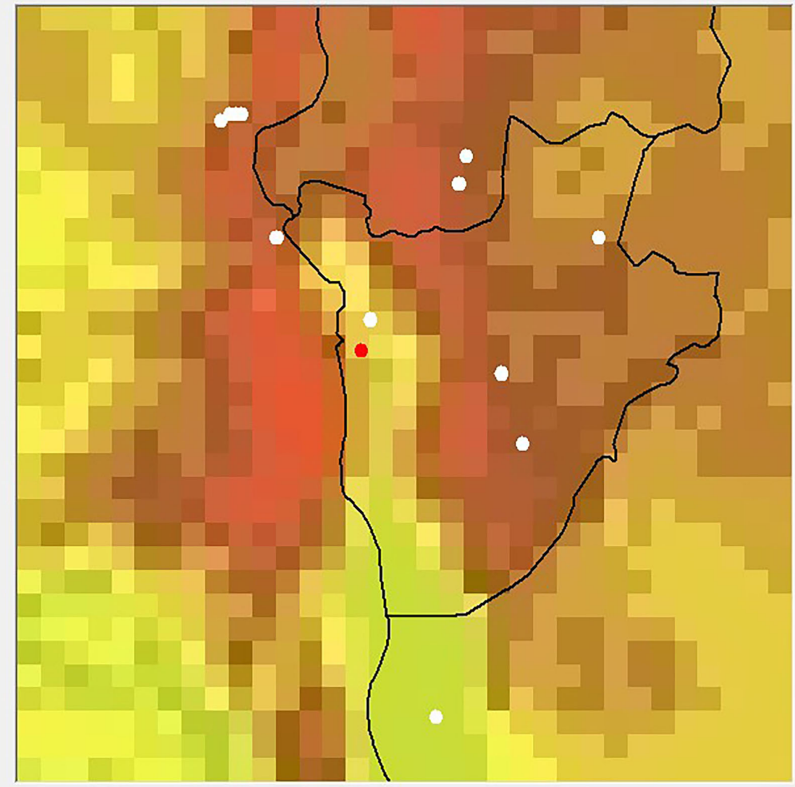

\begin{tabular}{|c|c|c|c|c|c|}
\hline $\begin{array}{r}N x \\
1 \\
2\end{array}$ & $\begin{array}{r}\text { Lon }\left[0^{\circ}\right] \\
30.33 \\
30\end{array}$ & $\begin{array}{l}\text { Lat }\left[0^{\circ}\right] \\
-2.83 \\
-3.71\end{array}$ & $\begin{array}{r}\text { Alt }[\mathrm{m}] \\
1755 \\
1850\end{array}$ & $\begin{array}{l}\text { Name } \\
\text { MUYINGA } \\
\text { LUVIRONZA }\end{array}$ & $\begin{array}{l}\text { Country } \\
\text { BURUNDI }\end{array}$ \\
\hline & & -3.31 & & BUTUMBUERA & $\begin{array}{l}\text { BUUUNDI } \\
\text { BURUNDI }\end{array}$ \\
\hline & 29.91 & -3.41 & 1719 & GITZGA & BURUNDI \\
\hline & 29.35 & -3.18 & 820 & IMBO (SEMS) & BURUNDI \\
\hline 6 & 29.73 & -2.6 & 1768 & BUTARE & NANDA \\
\hline & 29.76 & -2.48 & 1706 & RUBONA-COLLINE & RWANDA \\
\hline 8 & 29.63 & -4.88 & 885 & KIGOMA & TANzania \\
\hline 9 & 28.95 & -2.83 & 980 & LUBARIKA & DEM. REP. C \\
\hline 10 & 28.75 & -2.3 & 2055 & MULUNGU-TSHIBINDA & DEM. REP. C \\
\hline 11 & 28.8 & -2.3 & 1703 & MULUNGU-NYAMUNYUNYE & DEM. REP. \\
\hline & 28.71 & -2.33 & 2378 & MULUNGU-BUKULUMISA & DEM. REP. \\
\hline 13 & 28.78 & -2.3 & 1731 & MULUNGU-MOLZHE & DEM. REP. OF CONGO \\
\hline
\end{tabular}

(a)

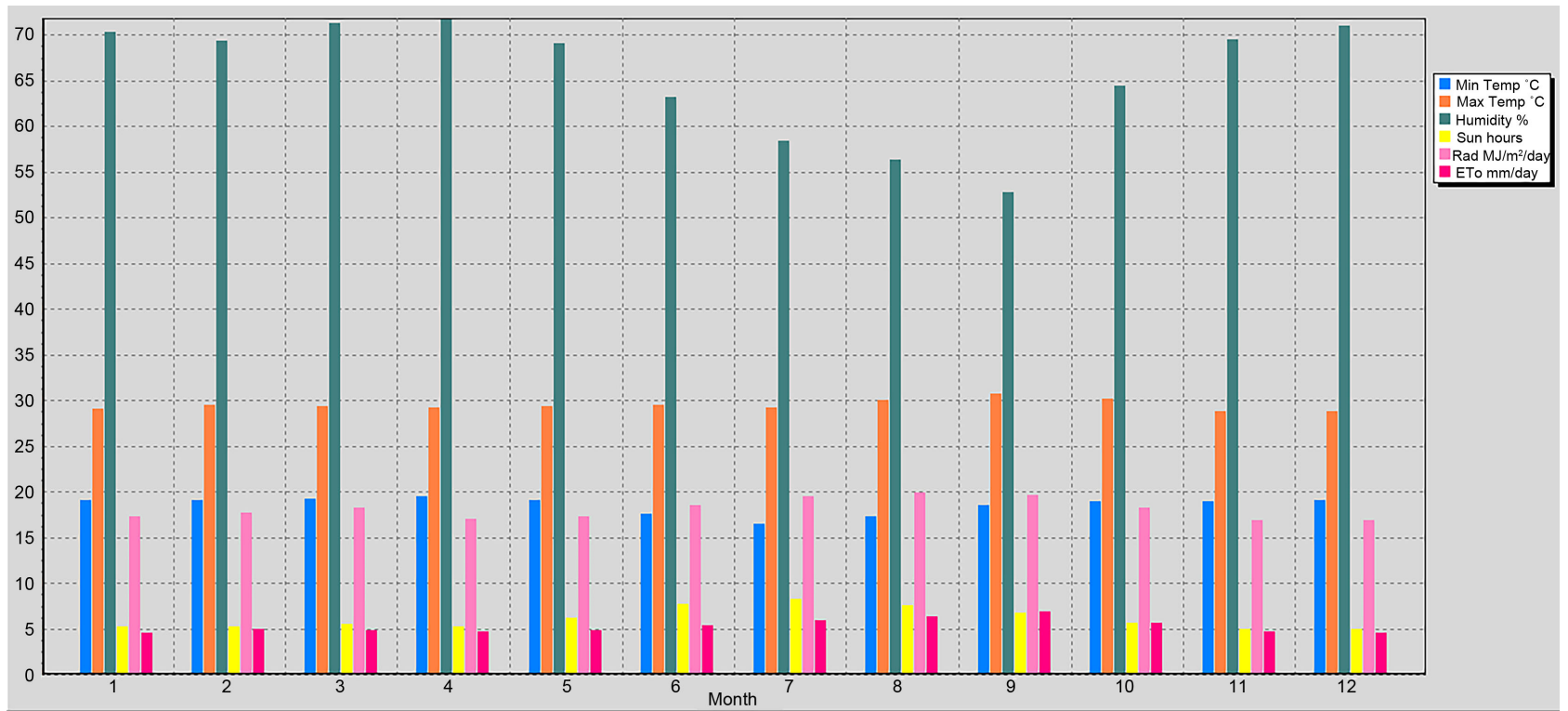

(b)

Figure 11. Monthly weather parameters variation in Bujumbura in 2021. (a). Map of the visualized site (see red point) with CLIMWAT 2.0 and CROPWAT 8.2 software duo-program developed by FAO. (b). Results for the five weather parameters surveyed.

ministry of this sector (the then Ministry of Water, Environment and Territorial Management) (Figure 13).

\subsubsection{Factor Five: Environmental Impact Rate}

The most commonly used environmental impact categories in LCIA (Life Cycle Impact Assessment) studies for sludge are acidification, eutrophication, global 


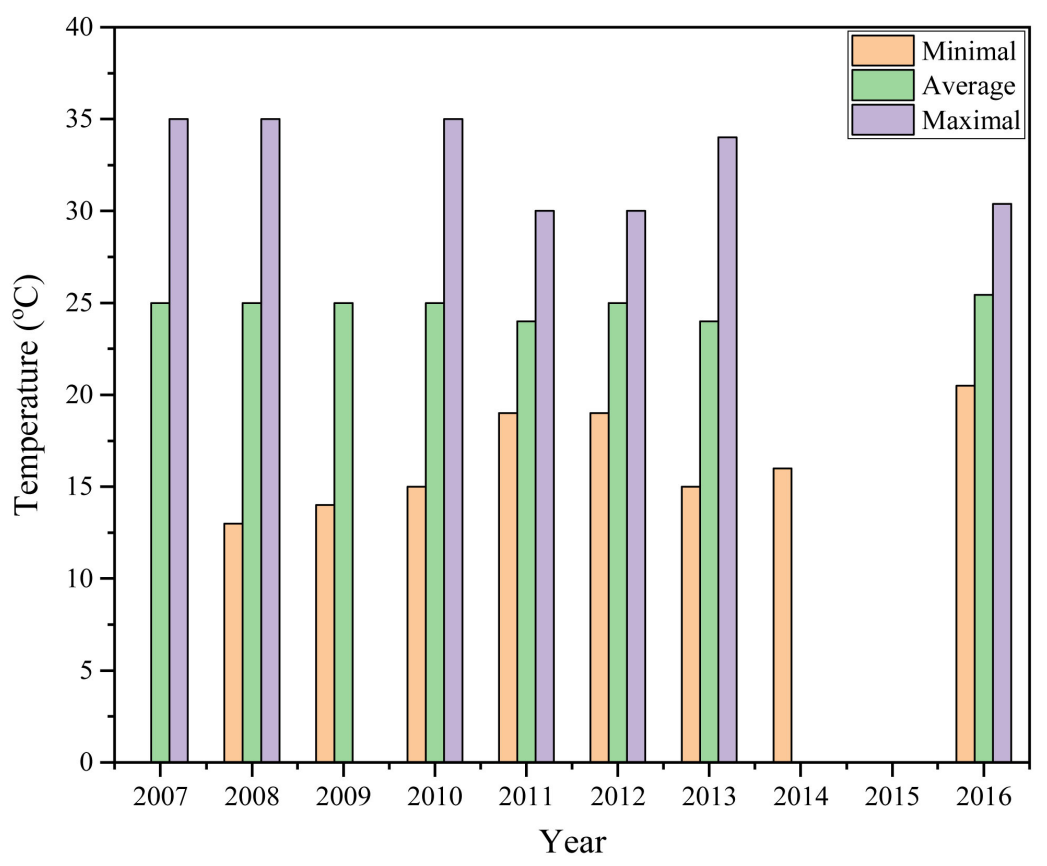

Figure 12. Annual temperature variation in Bujumbura (Data source: ISTEEBU).

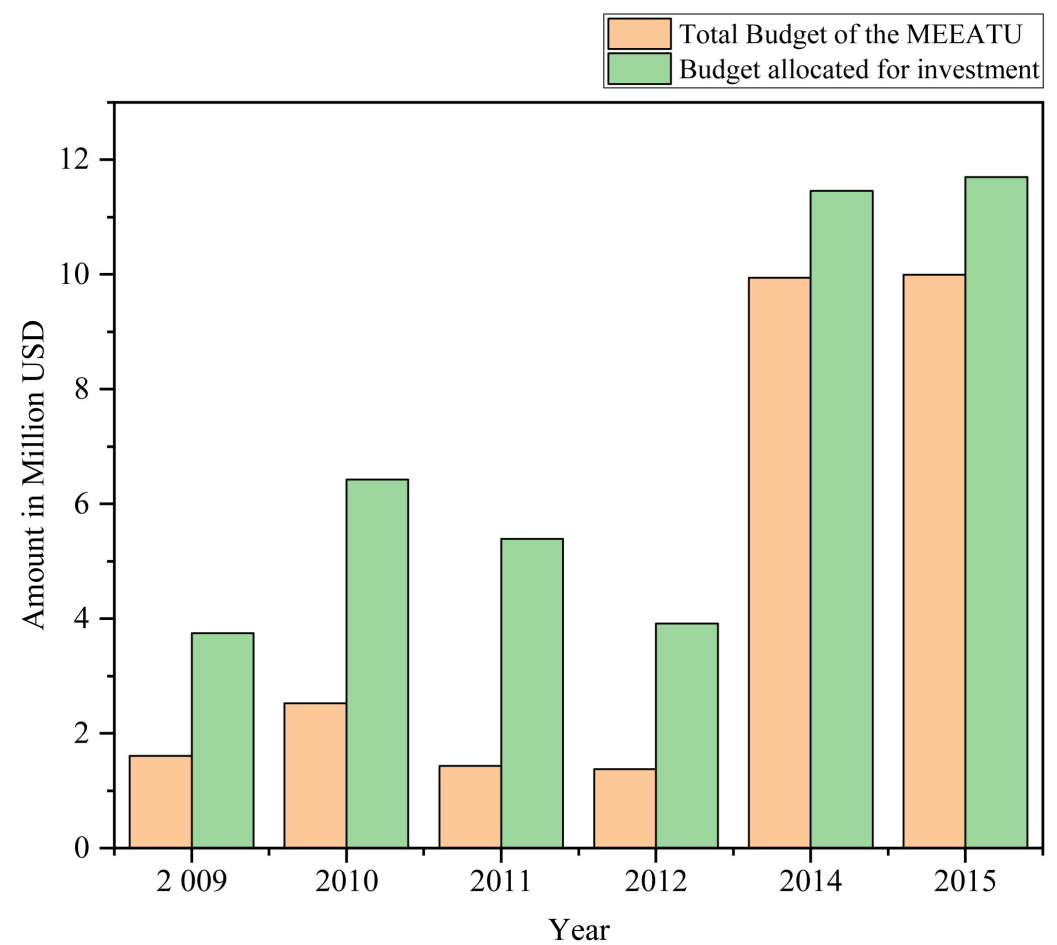

Figure 13. Budgetary allocation within MEEATU (the then ministry of water, environment and territorial management).

warming, photochemical ozone formation, ozone depletion, ecotoxicity, and resource consumption [30]. Well evidently, LCIA is meant to cover pollution at all the three major bodies of the environment (water, soil, and air). The seven treatment and disposal routes analyzed in this study have a higher or lower im- 
pact rate in different categories, according to the treatment processes and/or disposal mode applied.

The location of Bujumbura on the shore of Lake Tanganyika, a lake of an area larger than Burundi as a whole, arouses particular concerns for options leading to the pollution of this lake, on which the life of Bujumbura residents depends. The land slope allows runoff water and waters from flooding to easily vehiculate waste to the lake, land application of sludge should be avoided. Biosolids, in particular, have major drawbacks for use in agriculture and other applications; as a result, studies suggest that sludge or biosolids be sampled, controlled, and monitored for contaminants on a regular basis (pathogens, heavy metals, etc.). The most comprehensive sludge management studies show that land application is an important contribution to global warming, eutrophication, and acidification, despite their important role in energy production and crop production [27] [30]. This is the case of TR1, TR3, and TR5.

Conventional disposal methods such as incineration being known for involving enormous capital investment, the common challenge remains to minimize environmental impacts and economic cost of the process. It is important to know that for the time being, under any assumed local conditions, no such strategy can simultaneously reduce all environmental impacts [31].

Incineration is estimated as one of the best disposal methods for offering a higher mass solid reduction rate. However, scenarios involving incineration emit substances that impact mainly on human toxicity and ecotoxicities compared to other scenarios but if the energy is recovered and reused, the energy and heat produced can be used to offset the cost of emissions control. Flue gas must be well controlled, and bottom ash should be disposed of properly [27].

The last group comprises options using landfills. Landfilling can be a friendly disposal method if landfills are equipped to treat leachate and recover the produced biogas [27]. The maximum efforts should be made to achieve as much as higher impact reduction. Thus, if the landfill is selected, the leachate treatment system inevitably will consist of processes that generate a sludge which must be disposed of in a way that minimizes its environmental impacts [26].

\section{Discussion}

The study analyzed seven sewage sludge treatment and disposal routes (TR), which are: thickening-anaerobic digestion-dewatering-land application (TR1), thickening-conditioning-dewatering-sanitary landfill (TR2), thickening-conditioning-dewatering-anaerobic digestion-land application (TR3), thickening-conditioning-dewatering-drying-incineration (TR4), thickening-conditioning-dewatering-drying-land application (TR5), thickening-conditioning-dewateringincineration-sanitary landfill (TR6), and thickening-conditioning-dewateringdrying- sintering- building materials (TR7).

Basing on the characteristics of the study area and the literature review, five factors estimated the most influential were used to analyze the suitability, ad- 
vantage, and disadvantages of each of the seven routes designed. They are then summarized in Table 3.

Incineration and landfill are currently the most rated methods, for offering a good sludge disposal with lower environmental impacts. However, this study found that the capital investment for an incineration plant is too high for the financial capacity of the country, since a normal incineration plant may require an estimated budget higher than 6 times the total annual investment budget of the supervising ministry. A landfill is the remaining option in our target to offer a proper disposal, with precaution that leachate should be properly handled.

TR1, TR3, and TR5 have one characteristic in common, land application. Several studies have demonstrated that the environmental impact generated by this practice is higher. The local environmental code as well as the international ones already ratified do not support such methods, and the location of the city on the shore of Lake Tanganyika, slope, flooding phenomenon in the city, etc., all these amplify the risks for water pollution, leading to health issues. TR1 and TR3 in this trio to offer the possibility of energy recovery (anaerobic digestion), using sanitary landfilling instead of land application could be a good idea, to reduce environmental hazards. A study proved this energy potential when biogas was used to produce both electricity and heat, by covering $65 \%$ of the plant electrical demand, and heat (100\% of the plant requirements) [32].

TR2 is a decent disposal route. It does not neither use energy recovery nor dry sludge before disposal. This option might be characterized by a higher cost and difficulty in transporting sludge with higher moisture content.

TR4 and TR6 have incineration in common. TR4 has drying before incineration, which can profit the weather potential of the area, whereas TR6 does not dry but has landfilling after incineration. It can be estimated that TR4 offers energy recovery which can be sold to offset the system's running cost. TR6 is not

Table 3. The assessment matrix for suitability in key identified aspects.

\begin{tabular}{|c|c|c|c|c|c|c|}
\hline $\begin{array}{l}\text { Selected } \\
\text { routes }\end{array}$ & $\begin{array}{l}\text { Energy } \\
\text { recovery }\end{array}$ & $\begin{array}{l}\text { Local policies and } \\
\text { priorities }\end{array}$ & $\begin{array}{l}\text { Benefit from } \\
\text { local weather }\end{array}$ & $\begin{array}{l}\text { Environmental } \\
\text { impact }\end{array}$ & Affordability & Key observations \\
\hline TR1 & $\checkmark$ & $\square$ & $\square$ & $\boldsymbol{x}$ & $\nu$ & \\
\hline TR2 & $\square$ & $\nu$ & $\square$ & $\checkmark$ & $\checkmark$ & $\begin{array}{l}\text { For landfilling, leachate should be } \\
\text { controlled and treated properly [26] }\end{array}$ \\
\hline TR3 & $\checkmark$ & $\square$ & $\square$ & $\boldsymbol{x}$ & $\checkmark$ & \\
\hline TR4 & $\checkmark$ & $\boldsymbol{v}$ & $\checkmark$ & $\checkmark$ & $\ddot{*}$ & $\begin{array}{l}\text { Impact reduced if energy recovered } \\
\text { and reused [27] }\end{array}$ \\
\hline TR5 & $\boldsymbol{x}$ & $\square$ & $\checkmark$ & $\boldsymbol{x}$ & $\boldsymbol{v}$ & \\
\hline TR6 & $\checkmark$ & $\boldsymbol{\nu}$ & $\square$ & $\checkmark$ & $\boldsymbol{x}$ & $\begin{array}{l}\text { Including drying process could } \\
\text { increase the score }\end{array}$ \\
\hline TR7 & $\square$ & $\square$ & $\checkmark$ & $\square$ & $\nu$ & $\begin{array}{l}\text { A survey would be necessary to } \\
\text { assess the market viability [33] }\end{array}$ \\
\hline
\end{tabular}

Table Legend: $\boldsymbol{V}$ : An advantage offered by the route to a factor; $\boldsymbol{x}$ : A drawback or incompatibility $\square$ : Available potential for the TR; $\square$ : No observation. 
likely able to run the system at a low cost since heating sludge with high moisture content consumes enormous amount of energy.

TR7 has a unique disposal mode, using sludge for building materials. This scenario depends on the local market situation [33]. A survey in the population of Bujumbura could be the best way to conclude if the people would accept these materials since their durability as good as the currently used ones.

Among the seven routes analyzed, it is apparent that none is entirely compatible to the area studied. However, by simply modifying TR2, adding anaerobic digestion for energy recovery, and drying process which is cost-free with solar drying, we obtain a treatment and disposal route that can be recommendable for Bujumbura. That is, a route such as "thickening-anaerobic digestion-dewatering-drying-sanitary landfilling" would be a good choice. Further studies would be needed to estimate the biogas potential rate of the produced sludge, prior to system set up.

\section{Conclusion}

The approach proposed in this study aimed to find the most adapted sewage sludge treatment and disposal route, economically and environmentally friendly for sustainability. It is in the perspective of solving the dilemma caused by discrepancies observed in this area. Based on the seven routes widely used in China, this research analyzed each of them to each factor from the selected ones for the study area. The geographical position and the topographic condition of Bujumbura city in regard to Lake Tanganyika, put in danger the health of its residents when wastes are discharged directly or indirectly into Lake Tanganyika, on which life in Bujumbura and other cities around depends on drinking water. Polluting this lake results in higher water treatment costs or simple failure to supply clean water. Therefore, options using land application should be avoided de facto. Some methods of the conventional wastewater sludge treatment and disposal routes involve higher capital investment, especially incineration which was found not recommendable for Burundi, since it could cost the country up to 6 times the total investment budget of the supervising ministry. Regarding disposal, landfilling is estimated preferable with strict control of leachate. Thus, this study concluded that a route using anaerobic digestion, natural drying and landfilling would be a good choice for Bujumbura city.

\section{Acknowledgements}

First Author and Third Author are grateful to UNEP-Tongji Institute of Environment and Sustainable Development (IESD), Tongji University, for the research scholarship.

\section{Conflicts of Interest}

The authors declare no conflicts of interest regarding the publication of this paper. 


\section{References}

[1] Yoshida, H., Christensen, T.H. and Scheutz, C. (2013) Life Cycle Assessment of Sewage Sludge Management: A Review. Waste Management \& Research, 31, 1083-1101. https://doi.org/10.1177/0734242X13504446

[2] Mohammadi, Z., Azhdarpoor, A. and Dehghani, M. (2017) Stabilization and Dewatering of Wastewater Treatment Plant Sludge Using Combined Bio/Fenton-Like Oxidation Process. Drying Technology, 35, 545-552.

https://doi.org/10.1080/07373937.2016.1190938

[3] Ferreira, S.S., Piveli, R.P., Cutolo, S.A. and de Oliveira, A.A. (2013) Water Treatment Plant Sludge Disposal into Stabilization Ponds. Water Science \& Technology, 67, 1017-1025. https://doi.org/10.2166/wst.2013.652

[4] Tarrago, M., Garcia-Valles, M., Aly, M.H. and Martínez, S. (2017) Valorization of Sludge from a Wastewater Treatment Plant by Glass-Ceramic Production. Ceramics International, 43, 930-937. https://doi.org/10.1016/j.ceramint.2016.10.083

[5] Kumar, A., Chopra, A.K. and Kumar, V. (2017) A Review on Sewage Sludge (Biosolids) a Resource for Sustainable Agriculture. Archives of Agriculture and Environmental Science, 2, 340-347. https://doi.org/10.26832/24566632.2017.020417

[6] Gherghel, A., Teodosiu, C. and De Gisi, S. (2019) A Review on Wastewater Sludge Valorisation and Its Challenges in the Context of Circular Economy. Journal of Cleaner Production, 228, 244-263. https://doi.org/10.1016/j.jclepro.2019.04.240

[7] Burundi, G. (2018) Plan National de Développement 2018-2027 (PND Burundi 2018-2027). Burundi.

[8] Sommer, K., Guiébo, J., Vignol, R., Maréchal, N., Sublet, M. and Kuria, F. (2012) Burundi: Profil urbain de Bujumbura. ONU-Habitat.

https://unhabitat.org/sites/default/files/download-manager-files/Burundi\%20-\%20Buju mbura.pdf

[9] Bigumandondera, P., Nsavyimana, G., Ndikumana, T. and Vasel, J.-L. (2012) Vers une meilleur compréhension de l'assainissement non collectif en Afrique Subsaharienne intégrant les trois maillons de la chaine: Application à la ville de Bujumbura.

[10] Plisnier, P.-D., Nshombo, M., Mgana, H. and Ntakimazi, G. (2018) Monitoring Climate Change and Anthropogenic Pressure at Lake Tanganyika. Journal of Great Lakes Research, 44, 1194-1208. https://doi.org/10.1016/j.jglr.2018.05.019

[11] Polisi, A., Ntahorwaymiye, A.C., Agostini, P., Migraine, J.B., Kobayashi, M., Vaislic, M.D.H., Silverstein, S.J. and Jumaine, H. (2017) Burundi-Country Environmental Analysis: Understanding the Environment within the Dynamics of a Complex World: Linkages to Fragility, Conflict, and Climate Change. The World Bank.

[12] Quansah, A., Ntaryamira, T. and Rwemera, J. (2018) Sludge Wastewater Management by Conventional Treatment Process: Case Study-Bujumbura Municipal Sewage. International Journal of Sciences, 4, 52-65. https://doi.org/10.18483/ijSci.1542

[13] Oh, S.H., Park, K.H., Yu, B.H. and Kim, S.I. (2018) Drying Characteristics of Wastewater Sludge According to Outside Air Inflow Conditions. IDS 2018: 21 st International Drying Symposium, València, Spain, 11-14 September 2018, 1815-1821. https://doi.org/10.4995/IDS2018.2018.7790

[14] Li, B., Wang, F., Chi, Y. and Yan, J.H. (2014) Study on Optimal Energy Efficiency of a Sludge Drying-Incineration Combined System. Journal of Material Cycles and Waste Management, 16, 684-692. https://doi.org/10.1007/s10163-014-0293-3

[15] Bennamoun, L. (2012) Solar Drying of Wastewater Sludge: A Review. Renewable \& Sustainable Energy Reviews, 16, 1061-1073. 
https://doi.org/10.1016/j.rser.2011.10.005

[16] Collard, M., Teychene, B. and Lemee, L. (2017) Comparison of Three Different Wastewater Sludge and Their Respective Drying Processes: Solar, Thermal and Reed Beds-Impact on Organic Matter Characteristics. Journal of Environmental Management, 203, 760-767. https://doi.org/10.1016/j.jenvman.2016.05.070

[17] Bai, H., Zhu, R., An, H., Zhou, G.Y., Huang, H., Ren, H.Q. and Zhang, Y. (2019) Influence of Wastewater Sludge Properties on the Performance of Electro-Osmosis Dewatering. Environmental Technology, 40, 2853-2863. https://doi.org/10.1080/09593330.2018.1455744

[18] Pradel, M. (2019) Survey Data of Sewage Sludge Treatment and Disposal Routes Originated from Activated Sludge Water Treatment in France. Data in Brief, 26, Article ID: 104541. https://doi.org/10.1016/j.dib.2019.104541

[19] Stoll, U. and Parameswaran, K. (1996) Treatment and Disposal of Domestic Sewage Sludge and Nightsoil Sludge for Bangkok. Water Science \& Technology, 34, 209-217. https://doi.org/10.2166/wst.1996.0282

[20] Yasui, H., Matsuhashi, R., Noike, T. and Harada, H. (2006) Anaerobic Digestion with Partial Ozonation Minimises Greenhouse Gas Emission from Sludge Treatment and Disposal. Water Science \& Technology, 53, 255-263.

https://doi.org/10.2166/wst.2006.104

[21] Hatziconstantinou, G.J. and Efstathiou, H. (2003) Sludge Dewatering and Disposal Practices for Small Activated Sludge Wastewater Treatment Plants. Journal of Environmental Science and Health, Part A, 38, 2401-2412. https://doi.org/10.1081/ESE-120023444

[22] Werle, S. and Dudziak, M. (2014) Influence of Wastewater Treatment and the Method of Sludge Disposal on the Gasification Process. Ecological Chemistry and Engineering S, 21, 255-268. https://doi.org/10.2478/eces-2014-0020

[23] Bennamoun, L., Arlabosse, P. and Leonard, A. (2013) Review on Fundamental aspect of Application of Drying Process to Wastewater Sludge. Renewable \& Sustainable Energy Reviews, 28, 29-43. https://doi.org/10.1016/j.rser.2013.07.043

[24] Winkler, M. (1997) SLUDGE 6-Developments in Sludge Treatment and Disposal. Process Safety and Environmental Protection, 75, 58-59.

https://doi.org/10.1205/095758297528689

[25] Shaddel, S., Bakhtiary-Davijany, H., Kabbe, C., Dadgar, F. and Østerhus, S. (2019) Sustainable Sewage Sludge Management: From Current Practices to Emerging Nutrient Recovery Technologies. Sustainability, 11, 3435.

https://doi.org/10.3390/su11123435

[26] Elias, M.D., da Silva, L.F., Lima, L.S.M.D., Amorim, V.R., Hinojosa, M.A.G., Conde, A.L.F.M., Quintaes, B.R. and Campos, J.C. (2019) Co-Disposal of Sludge Generated during Landfill Leachate Treatment with Household Solid Waste. Desalination and Water Treatment, 159, 141-150. https://doi.org/10.5004/dwt.2019.23876

[27] Pradel, M., Reverdy, A., Richard, M. and Chabat, L. (2014) Environmental Impacts of Sewage Sludge Treatment and Disposal Routes: A Life Cycle Assessment Perspective. 4th European Conference on Sludge Management, Izmir, Turkey, May 2014, 8 p.

[28] Yang, G., Zhang, G. and Wang, H. (2015) Current State of Sludge Production, Management, Treatment and Disposal in China. Water Res, 78, 60-73. https://doi.org/10.1016/j.watres.2015.04.002

[29] Tehrani, F. and Haghi, E. (2015) Techno-Economic Assessment of Municipal Solid Waste Incineration Plant-Case Study of Tehran, Iran. The First Sustainable De- 
velopment Conference of Engineering Systems in Energy, Water and Environment, Tehran, 21 May 2015, 1-4.

[30] Taseli, B.K. (2020) Comparative Life Cycle Assessment of Sewage Sludge (Biosolid) Management Options. In: Taşeli, B.K., Ed., Sustainable Sewage Sludge Management and Resource Efficiency, IntechOpen, London.

[31] Ding, A., Zhang, R., Ngo, H.H., He, X., Ma, J., Nan, J. and Li, G. (2021) Life Cycle Assessment of Sewage Sludge Treatment and Disposal Based on Nutrient and Energy Recovery: A Review. Science of the Total Environment, 769, Article ID: 144451. https://doi.org/10.1016/j.scitotenv.2020.144451

[32] Neyens, E. and Baeyens, J. (2003) A Review of Thermal Sludge Pre-Treatment Processes to Improve Dewaterability. Journal of Hazardous Materials, 98, 51-67. https://doi.org/10.1016/S0304-3894(02)00320-5

[33] Tarantini, M., Butol, P. and Marorino, L. (2007) An Environmental LCA of Alternative Scenarios of Urban Sewage Sludge Treatment and Disposal. Thermal Science, 11, 153-164. https://doi.org/10.2298/TSCI0703153T 